\title{
Monitoring wastewater for assessing community health in cities: perspectives and a proposal
}

\author{
J. G. Tundisi ${ }^{a}$ (D), J. A. Garcia ${ }^{a *}$ (D), T. Matsumura-Tundisi ${ }^{a}$, J. E. M. Tundisi ${ }^{a}$, L. J. Patrizzi ${ }^{b}$ \\ and F. Ghiglieno ${ }^{c}$
}

anstituto Internacional de Ecologia, Rua Bento Carlos, 750, CEP 13560-660, São Carlos, SP, Brasil

'Serviço Autônomo de Água e Esgoto - SAAE, Av. Getúlio Vargas, 1500, Jardim São Paulo, CEP 13570-672, São Carlos, SP, Brasil

'Departamento de Física, Universidade Federal de São Carlos - UFSCar, Rod. Washington Luís, Km 235, SP-310, CEP 13565-905, São Carlos, SP, Brasil

*e-mail: analytics.garcia@gmail.com

Received: August 21, 2020 - Accepted: August 25, 2020 - Distributed: November 30, 2020

(With 1 figure)

At present more than 4 billion people live in cities therefore Planet Earth is a Urban Planet (Science, 2016). Since cities are a critical pathway of changes in life style, economy, and environment, it is important to standardize a common gathering program and creating a shared platform for collecting/accessing/analyzing all information in urban regions based on high quality data. This will enable the administration to be more effective in the implementation of new and advanced public policies. Furthermore, considering the crucial role that dynamic of the all processes in cities play on the environment, it is fundamental to monitor air, water and soil quality and pollution impacts in order to evaluate the potential effects on human health both in short-term and long-term. Equally important is to monitor the effects of bacteriological and virologic infectious diseases or pandemics such as COVID-19.

The coronavirus disease- COVID 19 impacts several aspects in human health, health security, economy and public administration and exposes several problems in cities in many countries (Daughton, 2020). In order to face the emergency, the use of a Wastewater Based Epidemiology Laboratory (WBEL) is a key tool to detect and monitoring COVID-19, its outbreaks expansion and geographical distribution in a city. As discussed by Daughton (2020) "[...] could rapidly establish the presence of COVID 19 across an entire community". However, the technology to use wastewater-based epidemiology as an early warning of outbreaks of infectious diseases (Mao et al., 2020) could well be expanded to be an efficient and effective instrument to detect a vast array of diseases affecting the human population in cities and the consequences of these diseases on the community.

Wastewater contains a large number of physical, chemical and biological components and indicators and it is a relevant source of past and present information about the health of the human populations. Human Health in cities is affected by a number of threats such as parasites in water and food, several infectious diseases, virus, bacteria, worms and protozoa. Dissolved organic components in water as endocrine disruptors, hormones, antibiotics, pesticides, herbicides, and other toxic substances are also diluted, and can be effectively monitored (Vaux Junior et al., 2020; Tundisi and Matsumura-Tundisi, 2020).

We propose here the implementation of a WASTEWATER MONITORING LABORATORY in cities as an early warning solution for detecting diseases and its potential impact on the human health in urban communities. In this perspective, a strong and synergic interdisciplinary effort in the search for several diseases will provide the city's public health system with a powerful tool to promote a permanent evaluation of the human health of a urban population. This will help to improve a public health policy based on information, statistics, indicators, implementing a data bank and providing conditions to improve new advances in the integrated management of water resources in cities, as well as to promote a better evaluation of the crosscorrelation between water analysis and the human health (Tundisi et al., 2015; Vaux Junior et al., 2020).

The surveillance of integral components of human health in wastewater is a complex and time-consuming process considering the traditional technologies to detect its conditions and status in cities. New and advanced protocols and methodology for the search of several diseases should be provided and developed as a guideline to this evaluation. This is a really new challenge for the scientific community working in research and development in this field. A new set of biochemical, protein and genetic indicators and sensors for real time monitoring, should be used by this Wastewater Monitoring Laboratory (Barras, 2018).

A preparation of a Public Health Index for the cities could be an important progress in the characterization of the health of the human population. An overview and data bank of existing diseases could be a valuable tool in the prevention. The following chart (Figure 1)- (modified from Mao et al., 2020) shows a roadmap of a surveillance program and the role of a WASTEWATER MONITORING LABORATORY as a permanent operating unity in a city and the possibilities of implementing a PUBLIC HEALTH INDEX based on the results obtained with the work of this facility. 


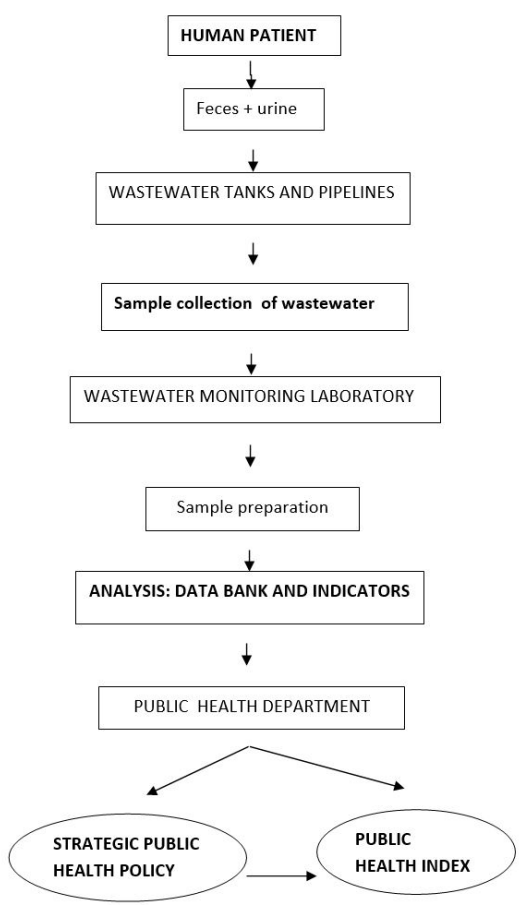

Figure 1. A chart showing the implementation of a working program of sampling, analysis and the proposition of a public policy health for a city based on a Wastewater Monitoring Laboratory.

\section{References}

BARRAS, C., 2018. Going to waste. Nature Medicine, vol. 24, no. 10, pp. 1484-1487. http://dx.doi.org/10.1038/s41591-0180218-0. PMid:30297901.

DAUGHTON, C.G., 2020. Wastewater surveillance for populationwide Covid-19: the present and future. The Science of the Total Environment, vol. 736, pp. 139631. http://dx.doi.org/10.1016/j. scitotenv.2020.139631. PMid:32474280.

MAO, K., ZHANG, K., DU, W., ALI, W., FENG, X. and ZHANG, H., 2020. The potential of wastewater-based epidemiology as surveillance and early warning of infectious diseases outbreaks. Current opinion in Environmental Science \& Health, vol. 17, pp. 1-7. http://dx.doi.org/10.1016/j.coesh.2020.04.006. PMid:32395676.

SCIENCE, 2016. Urban planet. Washington, pp. 904-947.

TUNDISI, J.G. and MATSUMURA-TUNDISI, T., 2020. A água. São Carlos: Scienza, pp. 130

TUNDISI, J.G., MATSUMURA TUNDISI, T., CIMINELLI, V.S. and BARBOSA, F.A., 2015. Water availability, water quality, water governance: the future ahead. Proceedings of the International Association of Hydrological Sciences, vol. 366, pp. 75-79. http:// dx.doi.org/10.5194/piahs-366-75-2015.

VAUX JUNIOR, H., VAMMEN, K., BERNEX, N., FABREGA, J., FORDE, M., ROLDAN, G. and TORREGOSA, M.L., 2020. The challenges of managing Urban Waters in the Americas. Environment, vol. 62, no. 2, pp. 15-29. 